\title{
Entrepreneurship and gender in higher engineering education in Germany
}

\author{
D. May ${ }^{1}$ \\ Research Associate \\ Engineering Education Research Group, Center for Higher Education, TU Dortmund \\ University \\ Dortmund, Germany \\ dominik.may@tu-dortmund.de \\ B. Hosch-Dayican \\ Research Associate \\ Professorship for Higher Education, Center for Higher Education, TU Dortmund Uni- \\ versity \\ Dortmund, Germany \\ bengue.dayican@tu-dortmund.de \\ L. Leisyte \\ Chair \\ Professorship for Higher Education, Center for Higher Education, TU Dortmund Uni- \\ versity \\ Dortmund, Germany \\ liudvika.leisyte@tu-dortmund.de \\ K. Lensing \\ Student Research Assistant \\ Engineering Education Research Group, Center for Higher Education, TU Dortmund \\ University \\ Dortmund, Germany \\ karsten.lensing@tu-dortmund.de \\ L. Sigl \\ Research Associate \\ Professorship for Higher Education, Center for Higher Education, TU Dortmund Uni- \\ versity \\ Dortmund, Germany \\ lisa.sigl@tu-dortmund.de \\ C. Terkowsky \\ Research Associate \\ Engineering Education Research Group, Center for Higher Education, TU Dortmund \\ University

\footnotetext{
${ }^{1}$ Corresponding Author

D. May, dominik.may@tu-dortmund.de
} 


\section{Dortmund, Germany \\ Claudius.terkowsky@tu-dortmund.de}

Keywords: entrepreneurship, gender, content analysis, engineering curricula

\section{INTRODUCTION}

In the past years European economic and employment policies increasingly underline the strategically important role of higher education institutions (HEls) in boosting Europe's innovation potential through supplying highly skilled labour [1]. Two key priorities are particularly emphasized: The first is to embed entrepreneurship into higher education curricula in order to further develop the knowledge triangle that integrates education, research, and innovation with each other [2]. This particularly counts for applied disciplines such as engineering [3]. The second priority is to enforce gender equality in labour force participation and increase representation of women in skilled employment [4] - which is again most evident in engineering - by incorporating gender issues in teaching plans and creating more awareness for gender balance in labour markets [5]. These objectives have subsequently been incorporated into national and regional policies. In Germany, funding for knowledge and technology transfer for economic and societal applications is already a central instrument in policy strategies of federal and state level ministries of education and science $[6,7]$.

The question is in how far these political demands are reflected in higher engineering education practice. In this study we focus on engineering curricula of nine leading technical universities to understand how entrepreneurship and gender studies have been incorporated in engineering programmes. Hence, this research brings together entrepreneurial and gender research with research on higher engineering education.

\section{Entrepreneurship and entrepreneurship education}

The expression entrepreneurship initially meant the course of undertaking a new task [8]. Today, the term entrepreneurship largely refers to risk taking in producing innovations, for example, through creating new companies [9]. Entrepreneurship is a subsuming term of particular expertise related to business skills, beyond those of engineering skills. Entrepreneurs have multiple tasks: "bringing the first product to the market and of building and financing a new organization. [...] Entrepreneurship is a high-risk, high-potential reward activity. In modern society, engineers are increasingly expected to move to positions of leadership and to take on additional roles as entrepreneurs. [...] In many regions, entrepreneurship is a significant source of new jobs and economic growth, and is strongly incentivised by governments and universities [...]" [8].

Entrepreneurship education in general can be described and defined as the means and approaches used to teach students to start novel businesses and run such businesses successfully [10]. Or as Aulets puts it: "Preparation for entrepreneurship, that is, the starting of a new company, involves unique competencies that can be learned" [11]. Entrepreneurial action includes breeding and identifying ideas with the potential to be developed into goods or services finding success in the market [12]. Students in engineering entrepreneurship programs generate competencies for team-work, effective communication, independent thinking, understanding business basics, design for end users, and open-ended problem solving [13]. Even though engineering entrepreneurship education is an emerging topic, its provision to engineering students seems 
not to be widespread at universities worldwide [14]. The inclusion of entrepreneurship, creativity and innovation in engineering education curricula demands a change in mind set and disposition on the part of teaching staff to partake in, or at least tolerate modifications in the engineering syllabus [13].

During the 1990s, quite a number of engineering schools established novel education programs, putting emphasis on engineering design skills and introduced aspects of social sciences into the syllabus of engineering design. These additions include

- science and technology studies

- user research with ethnographical methodology, and

- entrepreneurship and marketing development [8]

However, in most engineering education programs, these novel topics ended up as a add-ons without sufficient integration into engineering and sciences subjects, not contributing further to the disciplinary emptiness in engineering education syllabuses [15].

Recently, entrepreneurship education has emerged in different fashion in various engineering schools in Europe, Asia and the U.S. and engineering schools have reacted to a range of challenges with changing their views on entrepreneurship in engineering education:

- entrepreneurship is seen as an additional competence: engineering students should learn in dedicated courses making them able to sustain their predominately technology-driven perspective on innovation [16]

- entrepreneurship is provided through management and business courses especially for engineers: Management and business courses have been redesigned and adapted especially to the needs of engineers based on the idea of markets and economic processes creating the selection mechanisms that determine which technologies will survive [17]

- entrepreneurship is seen as critical thinking in engineering: entrepreneurship as critique and the capacity to provide significant problem solving for a society facing a series of new challenges that range from a

o restructuring of industrial mass production,

- globalization of trade and technology, and an

$\circ$ increased embedding of technology in social activities [18]

One example to address these additional skills of entrepreneurship is the CDIOSyllabus 2.0. It includes a section with the following topics: company founding, formulation, leadership, and organization; business plan development; company capitalization and finances; innovative product marketing; conceiving products and services around new technologies; the innovation system, networks, infrastructure, and services; building the team and initiating engineering processes [the engineering process according to the CDIO approach: conceiving, designing, implementing, and operating]; managing intellectual property. [8]

\section{The Gender Gap in Engineering Research and Entrepreneurship}

Entrepreneurship in engineering is an intersection of two gendered professional cultures and therewith particularly prone to a gender gap. It is a known fact that engi- 
neering is amongst the academic fields where the under-representation of women is most striking. While overall, women represent $37 \%$ of grade B academic staff and $20 \%$ of overall academic staff, figures for engineering are $23 \%$ and $11 \%$ [19]. Gender diversity in engineering organizations still had limited success and respective policy initiatives have met resistance, hostility or indifference by the managers as well as women engineers. It seems to require a cultural change in engineering environments, particularly also on the educational part of professional training [20]. Additionally, academic entrepreneurship has been discussed as being less attractive to women; amongst others because they were less likely to have received training in business and management or a lower preference for being self-employed [21].

Many attempts have been taken to overcome the gender gap in STEM fields by attracting and retaining more female students. One of the prominent approaches is to attract and retain more women in the STEM professions by making the curricula of natural science and engineering education more gender inclusive [22]. An inclusive curriculum can be incorporated into engineering programs in several ways, varying from designing the courses in a way that is responsive to the needs of students from different gender groups to introducing additional courses aiming at teaching gender and diversity competences to students. This implies that professional training for engineering students should include topics such as social justice, ethics, gender equality, and mechanisms of inclusion and exclusion as well as providing gender sensitivity examples and role models [23]. Universities in several countries have taken action in this regard to implement gender inclusiveness in engineering education. In Germany, there have been attempts to combine gender studies with technological sciences, for instance at the University of Hamburg by integrating a gender studies module into the Mathematics, Informatics and Natural Sciences Faculty [24]. In this new module, courses on gender and natural science have been offered at the introductory, advanced and research levels which, as later evaluations have shown, were hardly attended by students majoring in science and engineering studies. This demonstrated that there is a need to implement gender related courses directly within the faculties of science and engineering.

With respect to the gap in entrepreneurship in the STEM fields, literature has suggested different explanations including gaps in enrolment, gaps in female faculty mentorship, gaps in seniority/experience, funding and training gaps and job satisfaction priorities. Besides challenges within professional cultures, previous research also suggests that graduate training (environments) and postdoctoral training have relative importance in explaining the gender gap in STEM entrepreneurship [25]. Still however, gender aware entrepreneurship training is limited [26] and recent studies have identified an ongoing need for a contemporary image of women's entrepreneurship in Germany [27], which could introduce cultural change through awareness raising in general through gender sensitive curriculum in general which will be more likely to instil the interest in entrepreneurship among female students in entrepreneurial opportunities as well as raise their confidence to engage in high-risk entrepreneurship in technology.

\section{Research question and methodology}

In the above context, the aim of this paper is to explore the extent to which gender and entrepreneurship training are integrated in engineering training at universities in Germany and in this way the universities are responding to the policy imperatives at European and national levels. Curriculum descriptions serve as a data source for this study. We assume that if entrepreneurship and gender are taught at the universi- 
ties it must be visible in the official curricula descriptions. We pose two research questions:

- In how far are entrepreneurship and gender manifested in curricula of selected German technical universities based on the number of modules tackling these topics? and

- How prominent are the topics entrepreneurship and gender represented within the identified modules?

The methodology for this research is based on content analysis, which may be broadly defined as "any systematic reduction of a flow of text (or other symbols) to a standard set of statistically manipulable symbols representing the presence, the intensity, or the frequency of some characteristics relevant to social science" [28]. Amongst a variety of analysis techniques, one could distinguish between the basic categories of qualitative vs. quantitative, or thematic vs. relational types of content analysis. For addressing our research question the most relevant type appears to be the thematic content analysis (TCA), which "aims at an assessment of the (frequency of the) presence of specified themes, issues, actors, states of affairs, words or ideas in the texts or visuals to be analysed" [29]. In order to perform TCA one has to operationalize concepts using predetermined keywords, whereupon the frequency distribution of the keywords demonstrates whether the themes, issues or actors appear more or less frequently in the analysed data source [29]. In this paper we will make use of this merely descriptive procedure, and limit ourselves to generating descriptive inferences from the data at hand by focusing on frequency lists of selected keywords that represent entrepreneurship and gender diversity to address our research questions. Below we introduce our database and analysis procedure more in detail.

We examined the mechanical engineering curricula for bachelor and master level study programs (published between 2011 and 2014) from nine leading German technical universities (TU 9) as the main data source of this paper. In line with the TCA procedure, the curricula were analysed in terms of the appearance of entrepreneurship and gender as an explicit topic within the curriculum. The focus was put on mechanical engineering curricula, as this can be seen as the core discipline within the engineering field. Furthermore, especially in context with the gender topic the underrepresentation of female students in mechanical engineering is widely documented and discussed. Hence, this discipline is of special interest. For operationalizing entrepreneurship we used the terms (and its German equivalents) "entrepreneurship" (Unternehmertum) itself, "innovation" (Innovation), "venture"/"venturing" (Unternehmung), and "business" (Business/Unternehmen). Gender was operationalized by looking for the terms "gender" (Geschlecht), "diversity" (Diversität), and "inclusiveness" (Inklusivität). These keywords were generated by selecting the most frequently occurring words in literature on entrepreneurship and gender in engineering education to address the respective topics. They were then used as search terms to determine how frequent the topics of entrepreneurship and gender appear in the curricula. The universities and the examined documents can be seen in Table 1. 
Table 1. The analysed universities and documents

\begin{tabular}{|c|c|c|c|c|}
\hline \multirow{2}{*}{\begin{tabular}{|l|} 
University \\
Course of studies \\
\end{tabular}} & \multicolumn{4}{|l|}{ Document title } \\
\hline & Level (Bsc/M) & Release Date & Pages & Modules \\
\hline \multirow{2}{*}{$\begin{array}{l}\text { Technische Universität } \\
\text { München }\end{array}$} & \multicolumn{4}{|c|}{ Modulhandbuch 17400 Maschinenwesen; } \\
\hline & \multicolumn{4}{|c|}{ Modulhandbuch 16401 Maschinenwesen } \\
\hline \multirow{2}{*}{ Maschinenwesen } & Bachelor & 20.01 .14 & 679 & 312 \\
\hline & Master & 20.01 .14 & 957 & 259 \\
\hline \multirow{2}{*}{ RWTH Aachen University } & \multicolumn{4}{|c|}{ Prüfungsordnung für den Bachelorstudiengang Maschinenbau der RWTH, Anlage 1: Modulkatalog } \\
\hline & \multicolumn{4}{|c|}{ Prüfungsordnung für den Masterstudiengang Maschinenbau der RWTH, Anlage 1: Modulkatalog } \\
\hline \multirow{2}{*}{ Maschinenbau } & Bachelor & 16.03 .12 & 319 & 115 \\
\hline & Master & 31.03 .11 & 369 & 188 \\
\hline \multirow{2}{*}{$\begin{array}{l}\text { Technische Universität } \\
\text { Berlin }\end{array}$} & \multicolumn{4}{|c|}{ Modulkatalog Bachelor Maschinenbau SoSe 2013; } \\
\hline & \multicolumn{4}{|c|}{ Modulkatalog Master Maschinenbau SoSe 2013} \\
\hline \multirow{2}{*}{ Maschinenbau } & Bachelor & Summerterm 2013 & 215 & 102 \\
\hline & Master & Summerterm 2013 & 279 & 115 \\
\hline \multirow{2}{*}{$\begin{array}{l}\text { Karlsruhe Institute of } \\
\text { Technology }\end{array}$} & \multicolumn{4}{|c|}{ Modulhandbuch BSc Maschinenbau (Langfassung); } \\
\hline & \multicolumn{4}{|c|}{ Modulhandbuch MSc Maschinenbau (Langfassung) } \\
\hline \multirow{2}{*}{ Maschinenbau } & Bachelor & 01.10 .13 & 478 & 310 \\
\hline & Master & 24.10 .12 & 587 & 357 \\
\hline $\begin{array}{l}\text { Leibniz Universität } \\
\text { Hannover }\end{array}$ & \multicolumn{4}{|c|}{ Modulkatalog zur PO2010 - Studienführer für den Studiengang Maschinenbau } \\
\hline \multirow{2}{*}{ Maschinenbau } & Bachelor & Winter 2012/2013 & 113 & 51 \\
\hline & Master & Winter 2012/2013 & 113 & 267 \\
\hline \multirow{2}{*}{$\begin{array}{l}\text { Technische Universität } \\
\text { Braunschweig }\end{array}$} & \multicolumn{4}{|c|}{ Modulhandbuch: Bachelor Maschinenbau (BPO 2012); } \\
\hline & \multicolumn{4}{|c|}{ Modulhandbuch: Master Maschinenbau } \\
\hline \multirow{2}{*}{ Maschinenbau } & Bachelor & 2012 & 337 & 117 \\
\hline & Master & 24.08 .12 & 875 & 336 \\
\hline $\begin{array}{l}\text { Technische Universität } \\
\text { Darmstadt }\end{array}$ & \multicolumn{4}{|c|}{ Formblatt Modulbeschreibungen FB16 } \\
\hline \multirow{2}{*}{ Maschinenbau } & Bachelor & March 2007 & 114 & 57 \\
\hline & Master & March 2007 & 334 & 50 \\
\hline $\begin{array}{l}\text { Technische Universität } \\
\text { Dresden }\end{array}$ & \multicolumn{4}{|c|}{$\begin{array}{l}\text { Studienordnung für den Bachelor-Studiengang Maschinenbau Anlage 1: Modulbeschreibungen für } \\
\text { den Diplom-Aufbaustudiengang Maschinenbau; } \\
\text { Studienordnung für den Diplom-Aufbaustudiengang Maschinenbau Anlage 1: Modulbeschreibungen } \\
\text { für den Diplom-Aufbaustudiengang Maschinenbau }\end{array}$} \\
\hline \multirow{2}{*}{ Maschinenbau } & Bachelor & 17.07.13 & 97 & 76 \\
\hline & Master & 09.03 .12 & 96 & 90 \\
\hline University of Stuttaart & Modulhandbuc & gang Bachelor of Science & Maschinenbau; & \\
\hline & Modulhandbuc & gang Master of Science $\mathrm{M}$ & laschinenbau & \\
\hline & Bachelor & 25.03 .13 & 157 & 71 \\
\hline IViascrimentioa & Master & 27.03 .12 & 690 & 406 \\
\hline
\end{tabular}

Source: The documents were downloaded from the official universities' homepage

All in all we examined 1211 different module descriptions of mechanical engineering programmes at bachelor level and 2068 at master level at these nine universities. The addition of these two figures in order to find out the total number of examined modules is not expedient as some of the modules appear on bachelor as well as on master level. In general the module descriptions at the studied universities can be split into two to three main sections: The front page and the table of contents, the main body with the modules' descriptions, and finally in some cases there can be found an additional index or further explanations at the document's end. For the analysis we used only the part in the middle section. This means for the word count- 
ing that if a module has one of the search terms directly in its title, it appears at least three times in the document; once in the table of contents, once in the module description and once in the final index. For our research we counted the explicit term only once in this case in order to prevent distortion. Moreover, we counted it as often as it appeared within the module description, even if it appeared several times in one module. If a module for example had the word "entrepreneurship" in the title and additionally eight times in the description we counted the term nine times.

In addition to that, we differentiated between thematic relevant usage of terms in context with entrepreneurship and gender and thematic irrelevant usage. An example can be explained by looking at the term "business". If the word business was used in context with, let us say, business plan writing we counted it, as this shows an obvious connection with entrepreneurship. In contrast we did not count it if, for example, the word business was used in context with basic accounting. From our perspective in this case the term is not used in context with entrepreneurship in the narrow meaning. Building on this methodology a word counting was done on terms that are linked to entrepreneurship and gender. The results will be explained in the following.

\section{$4 \quad$ Findings}

As the topic entrepreneurship and gender were examined separately we present the findings one by one. In the first section we present data analysis in terms of word counts. We show how many modules tackle the examined topics. Further we study the identified modules and examine in which contexts entrepreneurship and gender are taught. Here we differentiate between modules, which have one of the topics as a main subject in its learning outcomes. On the other hand entrepreneurship and/or gender can be addressed in modules as one topic among others. This differentiation is important to rate the importance of entrepreneurship and gender within the curriculum. For us the underlying assumption is, that if these topics are of high importance they are represented by modules with a strong focus on them.

\subsection{Entrepreneurship}

To understand the usage of entrepreneurship in engineering curricula we searched the terms "entrepreneurship", "innovation", "venture/venturing", and "business". The search showed varied frequencies of different terms as shown in Table 2 below.

Table 2. Frequencies of terms in studied modules: Entrepreneurship

\begin{tabular}{|l|c|l|l|}
\hline \multirow{2}{*}{ Search terms } & \multirow{2}{*}{ Quantity of term appearance in documents } & $\begin{array}{l}\text { Quantity of modules using terms in titles } \\
\text { and/or in description }\end{array}$ \\
\cline { 3 - 5 } & & Bachelor level & Master level \\
\hline Entrepreneurship & 55 & 5 & 8 \\
\hline Innovation & 208 & 26 & 54 \\
\hline Venture/Venturing & 4 & 0 & 2 \\
\hline Business & 26 & 4 & 10 \\
\hline
\end{tabular}

As the terms were handled separately, the data in Table 2 is not yet adjusted in terms of double appearance of search terms. That means that if in one module description "entrepreneurship" and "innovation" appeared, this module was counted twice. Taking a closer look and deleting the modules that counted twice, has revealed that in total 32 modules at bachelor level and 67 modules at master level used the search terms in the title and/or in the description. Hence, these modules could be identified as modules that include the entrepreneurship topic. However, these results show clearly that the entrepreneurship topic (represented by the terms above) is not very much represented in the module descriptions. As we looked at 1211 module descriptions at bachelor level the 32 found modules just make up a proportion of $2.6 \%$. At master level this proportion is with $3.2 \%$ of 2068 modules slightly higher but still pret- 
ty low.

A second step for our data analysis was to study the importance of the entrepreneurship topic within the identified modules. It aimed to understand if this topic is in focus of the modules or is just one topic out of several others. For us this can serve as an additional evidence of the importance of entrepreneurship in engineering higher education. Thus we furthered the thematic content analysis of the identified modules by taking a second step in which we manually coded the content description and rated the importance of entrepreneurship as a subject within the module between "strong focus" and "one topic among others". Taking the figures from above and filtering out the modules with a strong focus shows that at bachelor level only 10 and at master level only 15 modules remained. This finally leads to the proportion of $0.82 \%$ (bachelor) and $0.73 \%$ (master), which again is pretty low. (See Table 3)

Table 3. Results of the second step TCA: Entrepreneurship

\begin{tabular}{|l|c|c|}
\hline \multirow{2}{*}{ Topic } & \multicolumn{2}{|c|}{ Quantity of modules having a strong focus on the entrepreneurship topic } \\
\cline { 2 - 3 } & Bachelor level & Master level \\
\hline Entrepreneurship & $10 / 1211=0,82 \%$ & $15 / 2068=0,73 \%$ \\
\hline
\end{tabular}

\subsection{Gender}

Just as for the terms on entrepreneurship the modules were examined in order to find the search terms on gender. These terms were "gender", "diversity", and "inclusiveness". The results are much more disappointing than for entrepreneurship (See Table 4).

Table 4. Frequencies of terms in studied modules: Gender

\begin{tabular}{|l|c|l|l|}
\hline \multirow{2}{*}{ Terms } & \multirow{2}{*}{ Quantity of term appearance in documents } & $\begin{array}{l}\text { Quantity of modules using terms in titles } \\
\text { and/or in description }\end{array}$ \\
\cline { 3 - 4 } & & Bachelor level & Master level \\
\hline Gender & 2 & 1 & 0 \\
\hline Diversity & 1 & 1 & 0 \\
\hline Inclusiveness & 0 & 0 & 0 \\
\hline
\end{tabular}

The findings show that the gender topic is barely represented in the module descriptions as seen in Table 4. The term "gender" appears twice und the term "diversity" only appears once in all of the module descriptions. Talking about the proportion of modules tackling the gender topic within the description the figures are insignificant low: $0.17 \%$ of the modules at bachelor level do show a connection to gender as a subject and none at the master level there could not be found even one.

Making the same second step for gender as we did for the entrepreneurship topic and finding out the modules that have gender as a main focus, only one module on bachelor level remains (proportion: 0.8\%) (Table 5).

Table 5. Results of the second step TCA: Gender

\begin{tabular}{|l|c|c|}
\hline \multirow{2}{*}{ Topic } & \multicolumn{2}{|c|}{ Quantity of modules having a strong focus on the gender topic } \\
\cline { 2 - 3 } & Bachelor level & Master level \\
\hline Gender & $1 / 1211=0,08 \%$ & - \\
\hline
\end{tabular}

\subsection{Conclusion and future work}

Based on the performed thematic content analyses of modules of mechanical engineering curricular at German technical universities we showed that the entrepreneur- 
ship topic is represented in most of the examined curricula, even if the way how it is represented differs significantly. On the one hand we find educational modules that fully address the entrepreneurship topic. On the other hand there are quite a number of modules that include it only in one or two parts of the full course. However, the results are not overwhelming. Looking at the proportion of modules on entrepreneurship in the curricula description clearly shows that not even $5 \%$ of the modules address this topic in any way, neither at bachelor nor at master level. Identifying the modules that have entrepreneurship in focus this proportion even declines to $1 \%$. These results differ significantly with the results on the gender topic. Only a very small amount of modules could be identified that include gender topic in module descriptions. Only in two of the modules we found the terms "gender" or "diversity" in its description and only one out of these two provides gender sensitivity training. In addition, we did not find any module where both entrepreneurship and gender topics were included in module description. Hence these two topics are still being kept separate in mechanical engineering curricula at German technical universities. Thus, the policy imperatives to integrate entrepreneurship training in engineering university education have been to some extent implemented, while we cannot see this for the inclusion of gender awareness training.

Thus it is still questionable how the policy demands should be fulfilled if the situation stays as it is. It can be assumed that if entrepreneurship and gender are not taught to a wider range at the universities, the future graduates will not acquire entrepreneurship and gender sensitivity skills. Furthermore, the fact that gender as a topic barely appears within the module description can be a reason for the on going underrepresentation of female students in engineering programs.

For further research we will go on researching these official program documents. As they were partly updated during the last year we will look into the new documents and check if and in how far the situation may have changed. Furthermore we will study in depth the examples where we identified the presence of entrepreneurship and gender topics. Specifically, we will examine how entrepreneurship and gender are taught, what types of learning outcomes are defined, what are the methodological approaches used in teaching these course and finally what are institutional contexts where these courses are provided. These will be the guiding questions for the future in order to identify best practice examples and to provide recommendations for teaching and learning designs in mechanical engineering. From our perspective these are necessary steps in order to improve engineering education and in this way to meet political as well as social demands of the future.

\section{REFERENCES}

[1] European Institute of Innovation \& Technology (EIT), "Catalyzing Innovation in the Knowledge Triangle. Practices from the EIT Knowledge and Innovation Communities" (2012), Luxembourg: Publications Office of the European Union.

[2] The Council of the European Union, "Conclusions of the Council and of the Representatives of the Governments of the Member States, Meeting within the Council, of 26 November 2009 on Developing the Role of Education in a FullyFunctioning Knowledge Triangle" in: Official Journal of the European Union (2009), 302, 3-5.

[3] Byers T., Seelig, T., Sheppart S., Weilerstein P., "Entrepreneurship: Its Role in Engineering Education", in: The Bridge - Linking Engineering and Society 
(2013), 43, 2, 35-40.

[4] European Commission, "Europe 2020. A strategy for smart, sustainable and inclusive growth" (2010), Brussels: European Commission.

[5] Sharp R., Franzway S., Mills J., Jill J., "Flawed Policy, Failed Politics? Challenging the Sexual Politics on Managing Diversity in Engineering Organization", in: Gender, Work and Organization (2012), Vol. 19 No. 6, 555-572.

[6] Bundesministerium für Bildung und Forschung, "Die neue Hightech-Strategie. Innovationen für Deutschland“ (2014), online available under: http://www.bmbf.de/pub/HTS_Broschure_barrierefrei.pdf

[7] Ministerium für Innovation, Wissenschaft und Forschung des Landes NordrheinWestfalen, „Forschungsstrategie Fortschritt NRW. Forschung und Innovation für nachhaltige Entwicklung 2013 - 2020" (2013), online available under:http://www.wissenschaft.nrw.de/mediathek/broschueren/

[8] Crawley E.F., Malmquist J., Östlund S., Brodeur D.R., Edström K.and Edward F. (2014), Rethinking Engineering Education - The CDIO Approach (second edition), Springer, Cham, Heidelberg, New york, Dordrecht, London.

[9] Menzel H.C., Aalito I. and Aalito U. (2007), On the way to creativity: Engineering as intraprenuership in organizations. Technovation, 27, 732-743.

[10] Tung, L.C., 'The Impact of Entrepreneurship Education on Entrepreneural Intention of Engineering Students', PhD thesis, City University of Hong Kong, 2011.

[11] Aulet B. (2013), Disciplined entrepreneurship: 24 steps to a successful startup. Wiley, Hoboken.

[12] Ward T.B., Cognition, creativity, and entrepreneurship, Journal of Business Venturing 19 (2004) 173-188

[13] Byers T, Seelig, T, Sheppart S, Weilerstein P., Entrepreneurship: Its Role in Engineering Education, in: The Bridge - Linking Engineering and Society (2013), 43, 2, 35-40.

[14] Abdulwahed M., Hamad J.A., Hasanain M., Hasna M.O, „Entrepreneurship Education in Engineering: A Literature Review, and an Integrated Embedment Proposal", in: Recent Ad-vances in Educational Methods, Proceedings of the 10th International Conference on Engineering Education (EDUCATION '13), Cambridge, UK February 20-22, 2013, 106-111

[15] Downey G. (2005), Are engineers losing control of technology? From 'problem solving' to 'problem definition and solution' in engineering education. Chemical Engineering Research and Design, 83, 583-595.

[16] Goldberg D. (2006), The entrepreneurial engineer, Wiley, New York.

[17] ASME (2008), Vision 2028 for mechanical engineering. (http://www.files.asme.org)

[18] Jorgensen U., Brodersen S., Lindegaard, H. and Boelskifte P. (2011), Foundations for a new type of design engineers: Experiences from DTU. Proceedings of the ICED 2011 Conference, Technical University of Denmark, August 15-18, 2011.

[19] She figures (2012): Gender in Research and Innovation. Statistics and Indicators, European Commission.

[20] Sharp, R., Franzway, S., Mills, J. and J. Gill (2012) Flawed Policy, Failed Politics? Challenging the Sexual Politics of Managing Diversity in Engineering Or- 
ganizations Gender, Work and Organization 19(6): 555-72.

[21] Verheul, Ingrid, Roy Thurik, Isabel Grilo, and Peter van der Zwan. 2012. "Explaining preferences and actual involvement in self-employment: gender and the entrepreneurial personality." Journal of Economic Psychology no. 33:325-341.

[22] J. E. Mills, M.E. Ayre and J. Gill (2008) Perceptions and understanding of gender inclusive curriculum in engineering education. In: SEFI 36th annual conference proceedings, Quality assessment, employability and innovation pp. 1-10.

[23] Béraud, A., Godfroy, A. S., Michel, J. (Eds.) GIEE 2011: Gender and Interdisciplinary Education for Engineers. Formation Interdisciplinaire des Ingénieurs et Problème du Genre (2012). Rotterdam: Sense Publishers.

[24] Götschel, H., "Gender and Science Studies Competence for Students in Engineering, Natural Sciences, and Science Education. The Project "Degendering Science" at the University of Hamburg, Germany", in: Béraud, A., Godfroy, A. S., Michel, J. (Eds.) GIEE 2011: Gender and Interdisciplinary Education for Engineers. Formation Interdisciplinaire des Ingénieurs et Problème du Genre (2012). Rotterdam: Sense Publishers, pp. 101-114.

[25] Blume-Kohout, M. E. (2014): Understanding the Gender Gap In STEM Fields Entrepreneurship, SBA Office for Advocacy, Available at: https://www.sba.gov/sites/default/files/Gender\%20Gap\%20in\%20STEM\%20Fiel ds_0.pdf, 2-3, 7

[26] Treanor, I. (2012) "Entrepreneurship education: exploring the gender dimension: A Gender and Enterprise Network, HEA sponsored, discussion workshop", International Journal of Gender and Entrepreneurship, Vol. 4 Iss: 2, pp.206-210.

[27] Ettl, K. and Welter, F. (2010) "Gender, context and entrepreneurial learning", International Journal of Gender and Entrepreneurship, Vol. 2 Iss: 2, pp.108-129.

[28] Shapiro, G. and Markoff, J. (1998) "Revolutionary Demands. A Content Analysis of the Cahiers de Doléances of 1789", Stanford, CA: Stanford University Press, p. 18.

[29] Pennings, P., Keman, H. and Kleinnijenhuis, J. (2006) "Doing Research in Political Science. $2^{\text {nd }}$ Edition”, London: Sage Publications, p. 58. 